147:494-503

15. Klinger JD, Cash HA, Wood RE, Miler JJ 1983 Protective immunization against chronic Pserudomonas aeruginosa pulmonary infection in rats. Infect Immun 39:1377-1384

16. Pier GB, Markham RB 1982 Induction in mice of cell-mediated immunity to Pseudomonas aeruginosa by high molecular weight polysaccharide and vinblastinc. J Immunol 128:2121-2125

17. Bedrossian CWM. Greenberg SD. Singer DB. Hansen JJ. Rosenberg HS 1986 The lung in cystic fibrosis. A quantitative study including prevalence of pathologic findings among different age groups. Hum Pathol 7:195-204
18. Esterly JR. Oppenheimer EH 1968 Observations in cystic fibrosis of the pancreas. III. Pulmonary lesions. Johns Hopkins Med J 120.94-101

19. Goldman DA. Klinger JD 1986 Pseudumonas cepacia: biology mechanisms of virulence, epidemiology. J Pediatr 108:806-812

20. Lam J. Chan R. Lam K. Costerton JW 1980 Production of mucoid microcolonies by Pseudomonas aeruginosa within infected lungs in cystic fibrosis. Infect Immun 28:546-556

21. Costerton JW, Lam J, Lam K. Chan R 1983 The role of the microcolony mode of growth in the pathogenesis of Pseudomonas aeruginosa infections. Rev Infect Dis 5:S867-S873

\title{
Announcement
}

\section{FASEB Summer Research Conferences \\ 1987 Series Completed, 1989 Topic Proposals Sought}

The sixth summer of the FASEB Summer Research Conference series has been completed. This summer there were 17 conferences held at two conference sites: Saxtons River, Vermont, and Copper Mountain, Colorado. The series was established to complement the large FASEB Annual Meeting. It was designed to provide quiet settings to encourage a relaxed exchange of information on the cutting edge of biomedical research. More than 1900 scientists from the United States and 18 foreign countries enjoyed the exciting science that was presented and discussed at the meetings in 1987.

Many of the 1987 conference participants requested that their conference topics be reschedulcd in the future FASEB Summer Research Conference series. Topic proposals are required from potential organizers of these conferences, as well as from those proposing new topics for consideration by the Conference Advisory Committee at its fall meeting.

The committce is seeking new topic proposals on subjects of keen interest to biological and medical researchers for fields that require concentrated 5-day programs for adequate discussions on the latest developments. A topic proposal outline is available from Dr. Robert W. Krauss, FASEB Executive Office (301-530-7093) to assist in the submission of proposals for FASEB Summer Research Conferences in 1989 or 1990.

The topics for the 1988 series have been set and are outlined below. The Conference Advisory Committee will meet in October or November of this year to establish the 1989 schedule and a tentative schedule for 1990.

\section{Saxtons River, VT}

Yeast RNA: Transcription, Splicing, Translation, Replication and Transposition June 12-17

Chairperson: Reed B. Wickner. NIADDK. NIH

Retinoids June 19-24

Chairperson: DeWitt S. Goodman. Columbia University College of P\&S

Smooth Muscle June 26-July 1

Chairperson: R. Kent Hermsmeyer, University of Nevada School of Medicine

Autoimmunity July 3-8

Chairperson: Howard L. Weiner, Brigham and Women's Hospital

Phospholipases July 10-15

Chairperson: Moseley Waite, Bowman Gray School of Medicine

Immunopharmacology July 17-22

Chairperson: Timothy Sullivan, University of Texas Health Science Center-Dallas

Structure and Function of Cell Membranes July 24-29

Chairperson: Philip L. Yeagle, SUNY at Buffalo

Somatic Cell Genetics July 31-August 5

Chairperson: Geoffrey Wahl. The Salk Institute

Receptors August 7-12

Chairperson: Richard Klausner, National Institutes of Health

Electrophysiological Mechanisms of Propagation in and Activation of Cardiac and Smooth Muscle August 14-19 Chairperson: David R. Harder, Medical College of Wisconsin

\section{Research Conferences}

\section{Copper Mountain, CO}

Neuroimmunomodulation July 26-July I

Chairperson: Novera H. Spector. University of Alabama at Birmingham

Ultradian and Infradian Modulation of the Circadian System July 3-8

Chairperson: Lawrence E. Scheving, University of Arkansas

Regulation of Gene Expression in Higher Animals by Hormones and Nutritional Substrates July 10-15

Chairperson: George A. Scheele, The Rockefeller University

Molecular Biology of Infectious and Parasitic Diseases July $17-22$

Chairperson: Richard A. Young, Whitehead Institute for Biomedical Research

Trichothecene, Blue-Green Algal and Marine-Toxins: Mechanisms, Detection and Therapy July 24-29

Chairperson: Adrianne Rogers, Boston University School of Medicine

Folic Acid, Vitamin B-12 and One-Carbon Metabolism July 31-Aug 5

Chairperson: Raymond Blakely, St. Judes Children's Research Hospital

Endothelium and Cardiovascular Function August 7-12 Chairperson: Paul M. Vanhoutte. Mayo Foundation

Neoplastic Transformation of Liver Cells August 14-19 Chairperson: Snorri Thorgiersson, National Cancer Institute, $\mathrm{NIH}$ 